\title{
Effectiveness of an integrated community, facility and media- based early child development intervention on caregiver knowledge and behavior: A quasi-experimental evaluation of the Malezi program in Tanzania
}

Gretchen Antelman ( $\nabla$ ga_zzz@yahoo.com )

Elizabeth Glaser Pediatric AIDS Foundation

\section{Josephine Ferla}

Elizabeth Glaser Pediatric AIDS Foundation

Michelle Gill

Elizabeth Glaser Pediatric AIDS Foundation

Hoffman Heather

George Washington University

Teopista Komba

Elizabeth Glaser Pediatric AIDS Foundation

\section{Amina Abubakar}

Institute for Human Development Aga Khan University, Nairobi

\section{Pieter Remes}

Development Media International, Mwanza

Ola Jahanpour

Elizabeth Glaser Pediatric AIDS Foundation

Martha Mariki

President's Office Regional and Local Government Dodoma

\section{Mary Mang'engya}

Ministry of Health

Roland van de Ven

Elizabeth Glaser Pediatric AIDS Foundation

\section{Research Article}

Keywords: Early child development, parenting, media intervention, community health workers, program evaluation, caregiver

Posted Date: March 7th, 2022

DOI: https://doi.org/10.21203/rs.3.rs-1377010/v1

License: (c) (i) This work is licensed under a Creative Commons Attribution 4.0 International License. Read Full License 


\section{Abstract}

\section{Background}

The quality of caregiving and the parent-child relationship is critical for early child development (ECD) and has been shown to be modifiable. This study evaluated an ECD project in Tanzania, assessing the effectiveness of radio messaging (RM) alone and a combined radio messaging/video job aids/ECD (RMV-ECD) intervention.

Methods

This two-arm pre-post evaluation study enrolled a cohort of caregivers of children 0-24 months in four districts of Tabora region, following them for nine months. ECD radio messages were broadcast on popular stations at least 10 times/day reaching all study districts. In two districts, community health workers (CHW) trained in UNICEF's Care for Child Development package and used ECD videos in home- and facility-based sessions with caregivers. We used pre-post analyses within intervention group to describe intervention effects on five outcomes: ECD knowledge, early stimulation, father engagement, responsive care, and environment safety; and logistic regression to describe the relative benefits of the combined intervention package (RMV-ECD) compared to radio messaging (RM) alone.

Results

In the RMV-ECD arm, all outcomes at endline except environment safety significantly improved after the intervention with the largest change seen in ECD knowledge (35.8\% increase, $p<.0001)$ and the smallest in father engagement $(6.7 \%, p=.015)$. In the RM arm, ECD knowledge $(5.7 \%, p=.031)$ and environment safety $(18.1 \%, p=<.0001)$ improved. In the comparative analysis, three outcomes showed significantly greater change in the RMV-ECD arm compared to the RM arm: ECD knowledge $(65.7 \%$ vs. $30.0 \%)$, early stimulation ( $49.5 \%$ vs. $31.2 \%$ ) and father engagement (35.4\% vs. $23.5 \%)$. High measures of parenting stress were associated with lower likelihood of having good ECD knowledge (AOR 0.50,95\%Cl: 0.35, 0.71), father engagement (AOR 0.72, 95\%Cl: 0.52, 0.99) and responsive care (AOR 0.31, 95\%Cl: 0.18, 0.54).

\section{Conclusions}

An intervention that includes mass media, educational video content and $\mathrm{CHWs}$ who counsel caregivers in their homes and health facilities was associated with significant improvements in ECD parenting knowledge and behaviors but effect on responsive care could not be established. Mass media alone was associated with improved parenting knowledge and household environment safety. Parenting stress was identified as a factor associated with ECD knowledge, early stimulation, father engagement and responsive care.

Trial registration

NCT05244161 at clinicaltrials.gov; retrospectively registered

\section{Introduction}

A lack of nurturing care, poverty, malnutrition, and socioeconomic disadvantage [1] drives an acute need to advance child developmental outcomes in sub-Saharan Africa, a region reported to have the highest prevalence $(>60 \%)$ of at-risk children facing substantial and cumulative threats to their development $[2,3]$. Responsive, sensitive care in the earliest years of life is critical for all domains of early child development (ECD), and for later school achievement and economic productivity in the adult years $[2,4,5]$. Further, the quality of caregiving and the parent-child relationship has been shown to be modifiable [6-10]. Systematic reviews $[11,12]$ have shown that standardized interventions aimed at supporting child development are successful in a variety of cultural and socio-economic contexts [7, 8], particularly in low to middle income countries [11].

There is a growing understanding, as documented in the 2018 Nurturing Care Framework [13] that the integration of health, nutrition, responsive caregiving, safety and security, and early learning interventions into existing services, is optimal for 
reaching children during the critical period from infancy to three years of age $[7,13,14]$. Interventions limited to health facility settings have demonstrated that video job aids can be effective education tools across a wide range of health topics [15] and a cost-effective way to reach caregivers [16]. But the use of multiple entry points, such as leveraging opportunities to engage community members through outreach or mass media, is critical to broadening the reach and impact of child development interventions $[4,5,7,8,12,17]$. Several studies have demonstrated that integrated, community and facility-based interventions can improve child nutrition and growth [18]; parenting behaviors [16, 19]; and cognitive and motor development [20-24]. In order to reach a broader audience, including family/household influencers such as fathers or grandparents, mass media radio messaging campaigns can increase caregiver and community knowledge, and caregiver motivation to seek appropriate health care [25-27].

Despite strong economic growth over the past decade, one-quarter of Tanzanians live in poverty [28], and about $70 \%$ of children in Tanzania are at risk of poor development [1]. Fortunately, the Government of Tanzania has shown a commitment to promoting ECD policies [29,30], and community health workers (CHW) have recently become a national cadre within the government's health system. While this new cadre and implementation of child development policy frameworks have not yet matured to scale, evaluations of programs that capacitate $\mathrm{CHWs}$ to support integrated child development interventions in Tanzania are especially timely.

This study evaluated phase II of the Malezi (caring for young children in Swahili) Project in Tabora, Tanzania. In phase I (201617), the Malezi Project supported the integration of an ECD package - based on UNICEF's Care for Child Development (CCD) package, adapted for Tanzania - into pregnancy and under-5 health services in selected districts of Tabora region. The training was focused on building providers' counseling skills and understanding the concept of responsive caregiving. The project also provided paper job aids, toys, and logistical/technical support for ongoing mentorship structures. After an internal evaluation showed the Malezi I intervention was feasible, acceptable, and effective by some measures of knowledge and parenting practices, the Malezi II Project expanded coverage of Malezi I in 2019, introducing an augmented intervention package including video job aids and a mass media campaign. This Malezi II evaluation study was designed to determine the comparative effectiveness of two interventions, radio messaging alone and a combined ECD package/video job aids/radio messaging intervention. Study outcomes were ECD knowledge, early stimulation, father engagement, responsive caregiving, and household environment safety/security.

The theory of change underlying the combined intervention package design draws on current evidence for parenting interventions [7, 12] and behavior change literature [31]. It proposes that a combination of caregiver attitudes and norms, informed by access to information at individual and community level, will increase caregiver knowledge, influence caregiver intentions, and ultimately their behaviors. While caregivers may develop an intention to change through program support, actual behavior change could be limited by a lack of skills or a less-enabling environment. We hypothesize that the combined intervention will have a stronger impact on caregiving behaviors, compared to radio messaging alone. Since the comprehensive Malezi II program model is resource intense, our study was designed to describe the relative benefits of the comprehensive intervention to change caregiver behaviors, compared to the benefits of radio messaging alone, which is potentially more efficient and scalable.

\section{Methods}

\section{Design and setting}

We conducted a two-arm quasi-experimental pre-post evaluation study, comparing different 9-month intervention packages to establish their relative impact on parenting skills and environment among a cohort of caregivers of children under age three years in Tabora region, located in central-western Tanzania and home to a predominantly rural (87\%) population. The study included four districts divided into two intervention groups. The first group (Kaliua, Uyui districts) was exposed to the minimal intervention package, composed of radio messaging (RM) only. The second group (Nzega, Igunga districts) was exposed to the 
Malezi Il full intervention package, composed of radio messaging, the introduction of short video job aids primarily for $\mathrm{CHW}$ use, and the CCD program (RMV-ECD), first implemented under the Malezi I phase and continued under Malezi II.

\section{Intervention}

ECD radio messages (37 different spots) and educational videos were aligned with Government policy and community tested prior to being aired on the three most popular radio stations in Tabora at least 10 times per day from March to December 2020. These spots focused on the importance of playing, talking with, and praising young children, using positive discipline, and the importance of both mothers and fathers interacting with young children. Radio messaging was targeted to reach all four study districts as much as possible, though coverage of some stations varied by district and proximity to urban centers.

CHWs in the RMV-ECD arm received training (February 2020) on how to use five short (5-6 minutes) ECD video job aids that were produced in Tabora and showed local caregivers and community health workers demonstrating recommended ECD practices (Swahili videos with English subtitles can be viewed at https://www.developmentmedia.net/project/malezi-ii/). Four of the videos concentrated on nurturing care practices specific to age groups (0-6 months, 6-12 months, 12-24 months, 2436 months) and one video covered cross-cutting issues, applicable to all ages. CHWs were provided with electronic tablets loaded with the videos for use in counseling caregivers attending clinic group or individual home sessions. All caregivers from the enrolled cohort were allocated to a CHW for monthly visits. Intervention fidelity monitoring data were collected monthly to document completion of $\mathrm{CHW}$ home visits to assigned caregivers.

\section{Sample and sampling procedures}

As the comprehensive program intervention was primarily delivered by $\mathrm{CHW}$ who were affiliated with health facilities, we purposefully selected 31 health facilities located in 29 administrative units called wards (6-8/district). From these wards, 75 National Bureau of Statistics census enumeration areas (EA) were randomly sampled proportional to population size. The study team aimed to enumerate all households in sampled EAs, listing potentially eligible households if there was a resident adult ( $\geq 18$ years) primary caregiver of a child aged 0-24 months who intended to remain in the same area for at least one year, and was willing to be home-visited by a CHW. From these listed households, only one caregiver per household was recruited. Caregivers who were not able to provide written informed consent due to a cognitive impairment or language barrier; or who were the primary caregiver of an index child with a congenital anomaly or other disability; or who worked as a $\mathrm{CHW}$ or medical provider, were excluded from the study.

We estimated that a sample size of 430 caregivers per intervention group would provide $90 \%$ power to detect a $15 \%$ difference between the RM and RMV-ECD intervention groups at endline, and $>80 \%$ power to detect at least a $5 \%$ change in each intervention group between baseline and endline, at a 5\% significance level. Of 8880 households enumerated, 1248 caregivers were recruited into the study and interviewed at baseline (October-December 2019, Fig. 1). Among these, 12 were withdrawn (10 refused after enrolment; two were excluded after being found ineligible for the study); one caregiver died; and 184 caregivers moved out of the area. Of the remaining $(n=1051)$ eligible for follow-up, $1004(96 \%)$ were successfully traced and interviewed at endline (January-March 2021). Almost all $(n=985 ; 98 \%)$ caregivers interviewed at endline remained the primary caregiver of the index child from baseline. Of the 19 caregivers whose index child had died or moved from the household, eight nominated an eligible "replacement" child under three years and 11 completed a partial interview skipping questions that were no longer applicable.

\section{Data collection and study variables}

Structured questionnaires were administered in a private place in or near the consenting caregiver's home in the national language (Swahili). We defined five outcome variables reflecting caregiver knowledge, stimulation practices, father engagement, responsive care, and household environment risk. Continuous scores for each variable were dichotomized at the median for analysis. Some scores, where the number of items differed by age of the child (early stimulation) or sub-group (environment risk), were standardized to a $0-1$ scale by dividing the raw score by the number of items. 
Age-appropriate ECD knowledge was assessed from six questions (scoring 0-6 points) asking the caregiver to describe one specific way that a "caregiver can support a child's mental, emotional or physical development..." during pregnancy, from birth to six months, from 6-9, 9-12, and 12-24 months and 2-5 years of age. Caregiver responses were recorded by the interviewer verbatim and coded by the co-Principal Investigator (JF) as correct or incorrect. Non-specific responses such as "seeking health care" were not considered correct.

Early stimulation practice and father engagement measures were adapted from questions originating from UNICEF's Multiple Indicator Cluster Surveys (MICS), a widely validated survey used in over 100 countries over the past two decades [32-34]. Caregivers of children under seven months could score up to three points for reporting that the mother, father, or other adult engaged the child in singing songs, taking the child outside, or playing with the child in the past week. Caregivers of children over seven months were asked three additional items (read books, told stories, name/count things with child) for a total of six points. The sum of the items for these two measures were then standardized to a 0-1 scale.

Responsive care was defined for caregivers of children over seven months based on interviewer observations of how the caregiver engaged with the child during the interview. This measure had a high proportion of missing data $(21 \%$ at baseline, $24 \%$ at endline) due to children being too young, sleeping or absent during the interview. The four items totaling up to six points included helping the child keep busy $(0,1)$, pointing out objects/naming things (scored as 0,1$)$, recognizing when the child needs help with something $(0,1,2)$, and keeping the child in view at all times $(0,1,2)$.

Household and neighborhood environment risks were assessed by interviewer observation of the inner and outer household areas, where risk groups were community (nearby road, bar/market, ditches); outside compound (open water source, unpenned animals, accessible sharp tools, chemicals or flammable materials, and unprotected cooking area); and inside household (accessible electric, medicine or cleaning chemicals, inappropriate toys). The environment risk outcome was standardized (01) to adjust for the different number of items in each group.

Several variables were explored to describe potential and actual exposure to the intervention. Radio ownership and recent $\mathrm{CHW}$ visits were assessed at baseline and endline in both study groups. Radio message content recall and frequency of radio listenership were assessed at endline in both study groups. Exposure to the intervention videos through home and facility visits was assessed in the RMV-ECD arm only at endline, and overall number of CHW visits was assessed in both study groups.

Other predictor and mediator variables included social-demographic characteristics assessed at baseline only, history of child illness/injury, health care utilization, parental discipline practices/beliefs, parenting stress, and depressive and anxiety symptoms. Health care utilization and parental discipline measures were adapted from the UNICEF MICS tool, where the discipline assessment contained 11 items, each answered "yes" or "no," and divided into four sub-groups: psychological, physical, severe physical and positive (non-violent) disciplinary practices by anyone in the household in the past month. The eight violent discipline items comprise the measure on violent discipline, and the three remaining non-violent items comprise the "positive discipline" measure. Discipline scores were standardized to a scale of 0-1.

The Parenting Stress Index (PSI) scale is a widely used and robust measure of three parenting related domains: Parental distress, parent-child relationship dysfunction (e.g. quality of relationship), and the extent to which the caregiver perceives the child is difficult [35]. The scale is composed of 36 statements (12 per sub-scale domain) which are scored 1 (strongly disagree) to 5 (strongly agree) and can be summed to reflect the total score for each domain. The PSI-36 total score is a composite score of the three subscales (scores range 36-180) with higher scores (or a cut-off of 90) indicating higher parental stress.

Depressive symptoms were measured using the 9-item Patient Health Questionnaire, a tool widely used in resource-limited settings and recently validated in a Tanzanian primary care population, showing $78 \%$ sensitivity and $87 \%$ specificity in detecting depression when compared to a gold-standard psychiatric assessment [36]. The General Anxiety Scale, often used in low to middle income country settings [37,38], measures the seven criteria of anxiety in the Diagnostic and Statistical Manual of Mental Disorders, establishing a provisional anxiety diagnosis and assessing symptom severity [39].

\section{Statistical analysis}

Page 5/25 
We summarized caregiver characteristics at baseline, and measures of covariates and intervention exposure at baseline and endline using frequencies and percentages for categorical variables and means, medians, interquartile ranges (IQR), and standard deviations (SD) for continuous variables. Characteristics and baseline outcome measures of participants in the two intervention arms at baseline were compared using Chi-Square or Rank Sum tests. We limited all analyses to those who were followed at endline, after conducting an attrition analysis which showed minimal statistically significant differences between those excluded and included (data not shown).

Intervention effects were assessed using McNemar's test and further described by the proportion of caregivers who improved from having a poor outcome score at baseline to having a good score at endline, with $95 \%$ confidence intervals (Cl) to allow comparison of intervention effect by study arm.

Unadjusted and adjusted logistic regression models that accounted for sampling weights and clustering by sampling unit were used to compare the effects of the full intervention arm (RMV-ECD) to the radio-only (RM) arm on study outcomes, as well as other covariables of interest. Baseline status of outcomes of interest and child age were included in adjusted models. All data management and descriptive analyses were done using Stata 16.1; regression analyses were done in SAS 9.4.

\section{Ethical considerations}

The protocol for this evaluation was approved by the National Research Ethics Committee of the Tanzania National Institute of Medical Research and the Advarra Review Board in the United States. Written consent was obtained from caregivers enrolled in the study.

\section{Results}

\section{Caregiver and index child characteristics}

Almost every caregiver $(n=1004)$ enrolled was the biological mother $(97.9 \%)$ with a median age of 26 years; the majority (84.5\%) were married or cohabiting (Table 1a). Almost one in five (19.2\%) had not completed primary education, and fewer (10.9\%) had more than a primary level education. The majority were farmers $(67.7 \%)$, and most caregivers (53.4\%) contributed no income to the household. More than one-third were food insecure weekly $(13.7 \%)$ or at least once in the past month (22.1\%). Only a few characteristics differed between the study arms. Caregivers in the RMV-ECD arm were more often partnered with more educated partners, had fewer under- 5 children in the household, and were less likely to be farmers, compared to caregivers in the RM arm.

Index children of caregivers were a median of 11-12 months of age at recruitment and 26 months at follow-up (Table 1b). Injury requiring medical attention in the past year was not uncommon ranging from 12.5\% in RMV-ECD arm at baseline to $24.0 \%$ of the RM arm at endline. The median parenting stress index score ranged from 70-72 across arms and time periods, and the proportion scoring above the cut-off $(>90)$ for high parenting stress was $19.0 \%(R M)$ and $20.2 \%$ (RMV-ECD) at baseline. This decreased slightly in both arms to $15.7 \%$ and $11.7 \%$ at endline. Most caregivers had no depressive or anxiety symptoms at either time period. Discipline scores, standardized to a scale of 0-1, may be interpreted as the proportion of caregivers who reported "yes" to one or more items within the subscale. Non-violent discipline practices were the most common and severe physical discipline was the least common type of discipline practiced. Violent and non-violent discipline subscale scores increased over time and in both arms, although this increase was confounded by child's age (data not shown). At endline, the RM arm had statistically higher rates of psychological (0.48) and physical discipline (0.43) practices compared to the RMVECD arm (0.37 and 0.34 respectively; $p<.0001)$.

\section{Intervention exposure}

Proxy and direct measures of intervention exposure are described in Table 1c. Radio access was lower in the RM arm (44.2\%) compared to the RMV-ECD arm $(56.5 \%, \mathrm{p}<.0001)$ at baseline and while access improved in both arms, the differential between the two arms became more pronounced at endline. Similarly, at endline, $54.7 \%$ of the RM arm reported hearing or recalling the 
ECD radio message compared to $74.6 \%$ of the RMV-ECD arm ( $p<.0001)$, though slightly more caregivers $(66.6 \%)$ in the $\mathrm{RM}$ arm reported hearing the messages at least weekly, compared to the RMV-ECD arm $(58.6 \%, p=.056)$.

At baseline, where the RMV-ECD arm had benefited from the Malezi I program, there was a slightly higher rate of receiving a $\mathrm{CHW}$ visit in the past year (11.5\%) compared to the radio-only arm (5.6\%, $\mathrm{p}=.002)$. During the intervention in the RMV-ECD arm, each CHW was assigned a median of five (IQR 4,7) caregivers to visit monthly during the intervention. From March to November 2020, a total of $4536 \mathrm{CHWs}$ visits to assigned caregivers were completed during the intervention period. Enrolled caregivers received a median of $8($ IQR 7,9$)$ visits during the intervention period and $84 \%$ received six or more visits. At endline, in the RM arm where CHW home visits were not supported, $2.9 \%$ reported a $\mathrm{CHW}$ home visit compared to $94.6 \%$ of the caregivers in RMV-ECD arm ( $p<.0001)$.

Remaining measures demonstrate the relatively high rate of exposure to the ECD videos (87.3\%) in the RMV-ECD arm, though videos were more likely to have been seen recently at home visits rather than at facility visits.

\section{Intervention effects}

We describe study outcomes in Table 2, first comparing RM and RMV-ECD arms at baseline (columns 2-4) to show the likely effect of the Malezi I intervention occurring prior to this study. ECD knowledge, early stimulation practices and "good" scores on environment/household safety are at significantly higher levels in the RMV-ECD arm compared to the RM arm at baseline; father engagement showed no difference and responsive care was lower in the RMV-ECD arm compared to the radio-only arm at baseline.

The within-arm change in study outcomes from baseline to endline estimates the "intent to treat" effect of each intervention (Table 2). The pre-post effect of RM and RMV-ECD interventions are estimated within arm by the proportion of caregivers who scored above the cutoff point ("good") at endline. Those who scored poorly at both baseline and endline, or who decreased from good (baseline) to poor (endline) are categorized as "poor".

For the RM arm, only ECD knowledge (27.7\% at baseline increasing to $33.6 \%$ at endline, $p=.031)$ and environment/household risks $(39.0 \%$ at baseline increasing to $57.1 \%$ at endline, $p<.0001)$ were significantly improved after the intervention (RM: columns 2,5,6). In the RMV-ECD arm, all outcomes except environment/household risks significantly improved after the intervention with the largest change seen in ECD knowledge (increase of $35.8 \%, p<.0001$ ) and the smallest change seen in father engagement (increase of 6.7\%, p=.015; RMV-ECD: columns 3,7,8).

In columns 9-10 of Table 2, we show the proportion of caregivers who shifted from scoring poorly at baseline to scoring well at endline by study arm. RM arm improvements ranged from 24-55\% while RMV-ECD improvements ranged from 35-66\% across study outcomes. Three of the five outcomes show significantly greater change in the RMV-ECD arm compared to the RM arm: ECD knowledge (30.0\% vs $65.7 \%)$, early stimulation (31.2\% vs. $49.5 \%)$ and father engagement ( $23.5 \%$ vs. $35.4 \%)$. In both study arms, the proportion of poorly scoring caregivers at baseline who improved by endline was over $50 \%$ for both responsive care and household environment risk outcomes, with no statistically significant difference between arms.

In Table 3, we show two adjusted logistic regression models on our study outcomes among caregivers from both study arms, examining the overall effect of the full RMV-ECD intervention compared to the RM intervention. The first model is adjusted for baseline level of the outcome and child age and the second model adds other variables of interest.

In model I, caregivers in the RMV-ECD arm were more likely than caregivers in the RM arm to score well in ECD knowledge (AOR 4.90, 95\% Cl: 3.16, 7.59), early stimulation (AOR 1.88, 95\% Cl: 1.36, 2.58), and father engagement (AOR 1.90, 95\% Cl: 1.45, 2.48), and a marginally significant protective effect was found on environment risks. There was no observed effect on responsive care (AOR 1.21, 95\% Cl: $0.78,1.86)$. In model II, we identified additional covariates that were significantly associated with the study outcomes. The common predictor across several study outcomes is parenting stress, where higher stress is associated with significantly lower likelihood of having good ECD knowledge (AOR 0.50, 95\% Cl: 0.35, 0.71), father engagement (AOR 0.72 , $95 \% \mathrm{Cl}: 0.52,0.99)$ and responsive care (AOR 0.31, 95\% Cl: 0.18, 0.54). Household assets (AOR 1.20, 95\%Cl: 1.01, 1.43) were 
associated with ECD knowledge and caregiver secondary education (AOR 2.33, 95\%Cl: 1.57, 3.61) was associated with early stimulation. Scoring higher (more likely) on the non-violent discipline score was associated with early stimulation (AOR 1.87, $95 \% \mathrm{Cl}: 1.58,2.22)$ and father engagement (AOR 1.59, 95\% Cl: 1.34, 1.87); while a higher violent discipline score (psychological, physical and severe physical items) was associated with lower likelihood of responsive care (AOR 0.88, 95\% Cl: 0.79, 0.97). Factors associated with higher environment/household risks include living in an extended family household (AOR 1.64, 95\% Cl: $1.32,2.05)$ and having a history of young child injury in the household (AOR $2.03,95 \% \mathrm{Cl}: 1.51,2.75)$. Caregivers whose children had the expected number of clinic visits (for their age) were less likely to score above the cutoff for environment/household risks (AOR 0.77, 95\%Cl: 0.62, 0.96).

\section{Discussion}

In the full Malezi program intervention arm (RMV-ECD) with radio messaging, trained facility providers, and CHW-provided CCD-based counseling at home and facility sessions using video job aids, caregivers significantly improved in ECD knowledge, early stimulation, father engagement and responsive care, but there was no observed effect on reduced household environment risks. Furthermore, the proportion of caregivers who scored poorly at baseline but improved at endline was significantly higher in the combined RMV-ECD arm compared to the radio messaging (RM) only arm for ECD knowledge, early stimulation, and father engagement, suggesting that a multi-pronged and multi-level intervention has a greater effect on study outcomes compared to a radio intervention with no additional health facility or community level engagement. Even after adjusting for baseline levels of the study outcomes and child age, caregivers in the full intervention arm were two to four times more likely to score well on ECD knowledge and early stimulation practice compared to caregivers in the radio-only arm. This finding is consistent with the recommendation that parenting interventions are most effective if they are integrated into existing health care systems coupled with provider training using an evidence-based curriculum and job aids. It is also important to provide opportunities for parents to practice behaviors and learn from provider feedback, all of which were components of the full Malezi program intervention [4, 12, 14]. Incorporating home-based ECD support, as the full Malezi program did, has also been key to some of the most successful ECD interventions [7, 20, 23].

The combined intervention had the strongest effect on ECD knowledge, with equal but weaker effects on early stimulation and father engagement, consistent with our conceptual model whereby increased knowledge would partly, but not exclusively, drive parenting behavior change. One notable strength of this evaluation is the relatively high fidelity to the intervention as demonstrated by our data on high coverage of monthly CHW visits to caregiver's homes, and frequent supervisory support (findings to be published separately). Several real-world evaluations of interventions requiring lay cadre to make home visits, particularly of programs implemented at scale [40], have faced challenges in ensuring coverage, intensity and quality of intervention delivery [41].

While we observed an improvement in responsive care in the combined intervention arm between baseline and endline, there was no effect of the radio-only intervention on responsive care, nor was there an observed effect of the combined intervention compared to the radio-only intervention. We cautiously interpret this finding to mean that there is weak or no evidence that either intervention improved responsive care behaviors. While some randomized trials have been able to improve responsive stimulation [21], infant attachment, or the mother-infant relationship [19], many other studies have only reported effects on parenting knowledge and practices $[18,22,23,42]$. The concept of responsive care may be difficult for lay cadre to teach. CHWs may not have the appropriate skills to addresses responsive care directly, while they may be more comfortable discussing the importance of play, communication, and specific ways parents could increase child stimulation. In a systematic review of parenting/ECD interventions, Jeong et al. describe several studies aiming to improve responsive care, and the methods used underscore the coaching intensity that may be required, with many employing recording of parent-child interactions to highlight and discuss opportunities for responsive caregiving [11].

Media communication campaigns can positively impact a wide range of child survival oriented parenting behaviors [25]. In Africa, given the widespread utilization of radio, these approaches are seen as effective tools for disseminating health information and supporting health-promoting behaviors [43], although effects of media-based interventions on behavioral 
endpoints are generally small $[44,45]$. In this study, the radio intervention alone was not linked to observed shifts in parenting behaviors, but it was shown to be effective in improving ECD knowledge among caregivers and household safety. Conversely, no reduction in household environment risks was observed in the combined intervention group. This may be explained by the higher proportion of caregivers in the radio-only group having such risks at baseline compared to caregivers in the combined intervention group. It is possible that the effect of the Malezi I program had already reduced risks among caregivers in the combined intervention group to a point where further reductions could be hard to achieve, while caregivers in the radio-only group were able to "catch up" after being exposed to radio messaging about ECD and child safety measures.

The addition of a multi-media component to a comprehensive health system-based intervention makes this intervention unique and has likely contributed meaningfully to the overall effects observed in the full intervention arm. The relatively small effect sizes in the radio-only arm, compared with the larger effects seen in the full intervention arm suggest that media messages heard by caregivers need reiteration, explanation and practical coaching to be sufficiently reinforced to drive parental behavior change [12]. The ECD video job aids, which illustrated messages in a video shown by tablet, allowed the CHW to stop, highlight and replay sections of the video for discussion. The videos also helped with delivery of standardized and complete ECD messages, adherent to the CCD curriculum (findings reported separately).

This study highlights the importance of two psychosocial-behavioral factors - parenting stress and discipline practices. Caregivers scoring above the cutoff for parenting stress were significantly less likely to score well on ECD knowledge, father engagement and responsive care. A study from Ghana finding comparable levels of parenting stress as this study, reported that stress was positively associated with depression in mothers [38]. Parenting stress may be conceptualized as a state whereby the caregiver does not have the emotional capacity or skills to cope with the cumulative demands of parenting leading to physical and emotional fatigue. Thus, parenting stress may deplete mental energy required to be emotionally supportive and provide developmental stimulation to the child. Studies show that higher parenting stress is related to less nurturing behavior, decreased enjoyment and increased conflict/punitive practices [46]. However, higher levels of perceived service availability have been shown to mediate the relationship between parenting stress and child neglect [47].

Non-violent discipline practices were associated with increased likelihood of early stimulation and father engagement, while violent discipline practices were associated with lower likelihood of responsive care. Discipline practices are a core parenting behavior and likely to be directly related to early stimulation and responsive care practices [48], although cultural differences in views of parental authority and respect for elders also shape discipline practices [49]. Embracing positive discipline instead of violent disciplinary practices is an important component of nurturing care: ensuring the child feels safe from emotional or physical abuse [50].

The Malezi program intervention did not include substantive messages or focused training of CHWs on how to support caregivers to positively discipline their child or cope with parenting stress, a notable content gap in many parenting interventions [11]. However, training providers to identify signs of high parenting stress or violent discipline practices, and to mentor caregivers more directly in positive discipline and managing stress, could have measurable effects on parenting behaviors and child development outcomes. One study found that peer-led group caregiver support intervention (12 fortnightly sessions) led to reduced depressive symptoms in mothers [8], and depression is likely correlated with parenting stress. UNICEF is also now promoting caregiver mental health as a training module to accompany CCD interventions, called Caring for the Caregiver (https://www.unicef.org/documents/caring-caregiver).

One limitation to this study was the reliance on self-reported measures for early stimulation and (mostly maternal) primary caregiver-reported father engagement. Similarly, while our responsive care measure was derived from observations during the interview, a more robust approach to data collection would have been to observe a standardized caregiver-child interaction session. Another limitation is that while we measured discipline practices and parenting stress at baseline and endline, we chose to associate the endline measures with our study outcomes because they were more proximate to the caregiver's recent behavior or state of mind. However, this means the observed associations are not established as causal factors, and it is possible that parenting stress may be caused by lower ECD knowledge or limited practice of child stimulation behaviors. 
Finally, this study was designed as a program evaluation with a relatively short intervention period. Thus, we intentionally focused on proximate outcomes - parenting knowledge and behaviors - rather than child development outcomes.

\section{Conclusions}

This study represents a rigorous and real-world program evaluation of an ECD project in Tanzania. An intervention that includes mass media, educational video content and CHWs who counsel and mentor caregivers in their homes and at health facilities was associated with significant improvements in ECD parenting knowledge and behaviors but effect on responsive care could not be established. The role of parenting stress and caregiver approaches to discipline were identified as key factors associated with ECD knowledge, early stimulation, father engagement and responsive care. Community-based parenting interventions targeting even the youngest children of 0-3 years could be improved by incorporating more messaging and caregiver coaching in positive discipline and managing parental stress. Future program design could also benefit from research that inquires more deeply into fathers' roles in creating a nurturing and safe environment for children.

\section{Abbreviations}

\begin{tabular}{ll} 
AOR & Adjusted odds ratio \\
\hline CCD & Care for Child Development (UNICEF) \\
\hline CHW & Community health worker \\
\hline CI & Confidence interval \\
\hline ECD & Early child development \\
\hline IQR & Inter-quartile range \\
\hline MICS & Multiple Indicator Cluster Surveys (UNICEF) \\
\hline OR & Odd ratio \\
\hline PSI & Parenting Stress Index (scale) \\
\hline RM & Radio messaging \\
\hline RMV-ECD & Radio messaging, video, early child development \\
\hline SD & Standard deviation
\end{tabular}

\section{Declarations}

Ethics approval and consent to participate: The protocol for this evaluation was approved by the National Research Ethics Committee of the Tanzania National Institute of Medical Research (NIMR/HQ/R.8a/Vol IX/3075) and the Advarra Review Board in the United States (Pro00034024). Written consent was obtained from caregivers enrolled in the study. All methods were carried out in accordance with relevant guidelines and regulations.

Consent for publication: not applicable

Availability of data and materials: The datasets used and/or analyzed during the current study are available from the corresponding author on reasonable request.

Competing interests: The authors declare that they have no competing interests

Funding: The research was supported by a grant (\#17424) from the Hilton Foundation to the Elizabeth Glaser Pediatric AIDS Foundation. 
Authors' contributions: GA, JF and MMG led the study design, protocol, data collection instrument development; and managed regulatory approvals. OJ, PR, MM, MAM contributed to the study design, protocol, data collection instrument development; JF and RV designed the Malezi interventions; and managed the Malezi Project team; PR led the design and production of the ECD videos. MM and MAM represented the program and evaluation interests to local government authorities. GA, JF, TK, OJ, RV supervised the study implementation team while TK supported fidelity data collection. GA, JF, TK cleaned/managed/coded the data. GA conducted descriptive analyses and wrote the manuscript and HH conducted the statistical analyses. JF, MMG, AA, RV contributed significantly to manuscript development and review while HH, TK, OJ, PR, MM, MAM reviewed the manuscript.

\section{Acknowledgements}

The authors would like to acknowledge the research staff at Elizabeth Glaser Pediatric AIDS Foundation (EGPAF) and CSK Research Solutions who supervised data collectors and supported data management; study staff who consented and interviewed participants; local government authorities and health facility staff who supported the program and evaluation and facilitated access to their communities. We would also like to thank Tamsen Rochat of the University of Witwaterstrand for her early contributions to the study design and protocol; colleagues from the Ministry of Health, Community Development, Gender, Elderly and Children and the President's Office of Regional and Local Government; and ECD specialists from the Conrad N. Hilton Foundation for their support of the study. Finally, we are grateful to the caregivers for their willingness to participate.

\section{References}

1. Lu C, Black M, Richter L. Risk of poor development in young children in low-income and middle-income countries: an estimation and analysis at the global, regional and country level. Lancet. 2016;4: e916-e922. doi:10.1016/S2214109X(16)30266-2

2. Black MM, Walker SP, Fernald LCH, Andersen CT, DiGirolamo AM, Lu C, et al. Early childhood development coming of age: science through the life course. Lancet. 2017;389: 77-90. doi:10.1016/S0140-6736(16)31389-7

3. Walker SP, Wachs TD, Grantham-McGregor S, Black MM, Nelson CA, Huffman SL, et al. Inequality in early childhood: risk and protective factors for early child development. Lancet. 2011;378: 1325-1338. doi:10.1016/S0140-6736(11)60555-2

4. Britto PR, Lye SJ, Proulx K, Yousafzai AK, Matthews SG, Vaivada T, et al. Nurturing care: promoting early childhood development. Lancet. 2017;389: 91-102. doi:10.1016/S0140-6736(16)31390-3

5. Shonkoff JP, Radner JM, Foote N. Expanding the evidence base to drive more productive early childhood investment. Lancet. 2017;389: 14-16. doi:10.1016/S0140-6736(16)31702-0

6. Yousafzai AK, Rasheed MA, Rizvi A, Armstrong R, Bhutta ZA. Parenting Skills and Emotional Availability: An RCT. Pediatrics. 2015;135: e1247-57. doi:10.1542/peds.2014-2335

7. Richter LM, Daelmans B, Lombardi J, Heymann J, Boo FL, Behrman JR, et al. Investing in the foundation of sustainable development: pathways to scale up for early childhood development. Lancet. 2017;389: 103-118. doi:10.1016/S01406736(16)31698-1

8. Singla DR, Kumbakumba E, Aboud FE. Effects of a parenting intervention to address maternal psychological wellbeing and child development and growth in rural Uganda: A community-based, cluster-randomised trial. Lancet. 2015;3: e458e469. doi:10.1016/S2214-109X(15)00099-6

9. le Roux IM, Tomlinson M, Harwood JM, O'Connor MJ, Worthman CM, Mbewu N, et al. Outcomes of home visits for pregnant mothers and their infants: a cluster randomized controlled trial. AIDS. 2013;27: 1461-1471.

doi:10.1097/QAD.0b013e3283601b53

10. Richter L, Rotheram-Borus MJ, Van Heerden A, Stein A, Tomlinson M, Harwood JM, et al. Pregnant women living with HIV (WLH) supported at clinics by peer WLH: A cluster randomized controlled trial. AIDS Behav. 2014;18: 706-715. doi:10.1007/s10461-014-0694-2

11. Jeong J, Franchett EE, Ramos de Oliveira C V., Rehmani K, Yousafzai AK. Parenting interventions to promote early child development in the first three years of life: A global systematic review and meta-analysis. PLoS Med. 2021;18: 1-51.

Page $11 / 25$ 
doi:10.1371/journal.pmed.1003602

12. Lucas JE, Richter LM, Daelmans B. Care for Child Development: an intervention in support of responsive caregiving and early child development. Child Care Health Dev. 2018;44: 41-49. doi:10.1111/cch.12544

13. World Health Organization, UNICEF WB. Nurturing care for early child development: A framework for helping children survive and thrive to transform health and human potential. Geneva, Switzerland; 2018.

14. Engle PL, Fernald LCH, Alderman H, Behrman J, O'Gara C, Yousafzai A, et al. Strategies for reducing inequalities and improving developmental outcomes for young children in low-income and middle-income countries. Lancet. 2011;378: 1339-1353. doi:10.1016/S0140-6736(11)60889-1

15. Tuong W, Larsen ER, Armstrong AW. Videos to influence: a systematic review of effectiveness of video-based education in modifying health behaviors. J Behav Med. 2014;37: 218-233. doi:10.1007/s10865-012-9480-7

16. Chang SM, Grantham-McGregor SM, Powell CA, Vera-Hernandez M, Lopez-Boo F, Baker-Henningham H, et al. Integrating a Parenting Intervention With Routine Primary Health Care: A Cluster Randomized Trial. Pediatrics. 2015;136: 272-280. doi:10.1542/peds.2015-0119

17. Swigart T, Hollowell J, Remes P, Lavoie M, Murray J, Belem M, et al. Can health promotion videos 'go viral'? A nonrandomised, controlled, before-and-after pilot study to measure the spread and impact of local language mobile videos in Burkina Faso. Glob Health Action. Taylor \& Francis; 2019;12: 1600858. doi:10.1080/16549716.2019.1600858

18. Rockers PC, Fink G, Zanolini A, Banda B, Biemba G, Sullivan C, et al. Impact of a community-based package of interventions on child development in Zambia: A cluster-randomised controlled trial. BMJ Glob Heal. 2016;1: 1-10. doi:10.1136/bmjgh-2016-000104

19. Cooper PJ, Tomlinson M, Swartz L, Landman M, Molteno C, Stein A, et al. Improving quality of mother-infant relationship and infant attachment in socioeconomically deprived community in South Africa: Randomised controlled trial. BMJ. 2009;338: 997. doi:10.1136/bmj.b974

20. Yousafzai AK, Obradović J, Rasheed MA, Rizvi A, Portilla XA, Tirado-Strayer N, et al. Effects of responsive stimulation and nutrition interventions on children's development and growth at age 4 years in a disadvantaged population in Pakistan: a longitudinal follow-up of a cluster-randomised factorial effectiveness trial. Lancet. 2016;4: e548-e558.

doi:10.1016/S2214-109X(16)30100-0

21. Yousafzai AK, Rasheed MA, Rizvi A, Armstrong R, Bhutta ZA. Effect of integrated responsive stimulation and nutrition interventions in the Lady Health Worker programme in Pakistan on child development, growth, and health outcomes: A cluster-randomised factorial effectiveness trial. Lancet. 2014;384: 1282-1293. doi:10.1016/S0140-6736(14)60455-4

22. Hamadani JD, Huda SN, Khatun F, Grantham-McGregor SM. Psychosocial stimulation improves the development of undernourished children in Rural Bangladesh. J Nutr. 2006;136: 2645-2652. doi:10.1093/jn/136.10.2645

23. Powell C, Baker-henningham H, Walker S, Gernay J, Grantham-mcgregor S. Feasibility of integrating early stimulation into primary care for undernourished Jamaican children: Cluster randomised controlled trial. Prim Care. 2004;329. doi:10.1136/bmj.38132.503472.

24. Muhoozi GKM, Atukunda P, Diep LM, Mwadime R, Kaaya AN, Skaare AB, et al. Nutrition, hygiene, and stimulation education to improve growth, cognitive, language, and motor development among infants in Uganda: A clusterrandomized trial. Matern Child Nutr. 2018;14: 1-11. doi:10.1111/mcn.12527

25. Naugle DA, Hornik RC. Systematic review of the effectiveness of mass media interventions for child survival in low-and middle-income countries. J Health Commun. 2014;19: 190-215. doi:10.1080/10810730.2014.918217

26. Sarrassat S, Meda N, Badolo H, Ouedraogo M, Some H, Bambara R, et al. Effect of a mass radio campaign on family behaviours and child survival in Burkina Faso: a repeated cross-sectional, cluster-randomised trial. Lancet. 2018;6: e330e341. doi:10.1016/S2214-109X(18)30004-4

27. Murray J, Head R, Sarrassat S, Hollowell J, Remes P, Lavoie M, et al. Modelling the effect of a mass radio campaign on child mortality using facility utilisation data and the Lives Saved Tool (LiST): findings from a cluster randomised trial in Burkina Faso. BMJ Glob Heal. 2018;3: e000808. doi:10.1136/bmjgh-2018-000808

Page $12 / 25$ 
28. National Bureau of Statistics, United Nations Children's Fund. Child Poverty in Tanzania. 2016.

29. Government of Tanzania. National Multisectoral Early Childhood Development Stakeholders' Forum [Internet]. 2018. Available: https://nurturing-care.org/wp-content/uploads/2020/10/Tanzania-Proceedings.pdf

30. L M. Scaling up Early Childhood Development in Tanzania First national multi-sectoral programme in the country [Internet]. 2020. Available: https://www.unicef.org/tanzania/stories/scaling-early-childhood-development-tanzania

31. Fishbein M, Yzer MC. Using Theory to Design Effective Health Behavior Interventions. Commun Theory. 2003;13: 164-183. doi:10.1111/j.1468-2885.2003.tb00287.x

32. UNICEF. Collecting data on foundational learning skills and parental involvement in education: Division of Data, Research and Policy. 2017.

33. UNICEF. Development of the Early Childhood Development Index in MICS surveys. 2017.

34. Young Chlidren Affected by HIV and AIDS: Monitoring and Evaluation Learning Report 2019 [Internet]. Available: https://www.hiltonfoundation.org/wp-content/uploads/2020/06/2019-YCABA-MEL-Report.pdf

35. Abidin R. Parenting Stress Index (PSI). Charlottesville VA: Pediatric Psychology Press; 1990.

36. Smith Fawzi MC, Ngakongwa F, Liu Y, Rutayuga T, Siril H, Somba M, et al. Validating the Patient Health Questionnaire-9 (PHQ-9) for screening of depression in Tanzania. Neurol Psychiatry Brain Res. Elsevier; 2019;31: 9-14. doi:10.1016/j.npbr.2018.11.002

37. Chibanda D, Benjamin L, Weiss HA, Abas M. Mental, neurological, and substance use disorders in people living with HIV/AIDS in low- and middle-income countries. J Acquir Immune Defic Syndr. United States; 2014;67 Suppl 1: S54-67. doi:10.1097/QAl.0000000000000258

38. Guo N, Bindt C, Te Bonle M, Appiah-Poku J, Tomori C, Hinz R, et al. Mental health related determinants of parenting stress among urban mothers of young children-results from a birth-cohort study in Ghana and Cote d'Ivoire. BMC Psychiatry. 2014;14: 156. doi:10.1186/1471-244X-14-156

39. DSM-III and the transformation of American psychiatry: a history. Am J Psychiatry. 1993;150: 399-410. doi:10.1176/ajp.150.3.399

40. Galasso E, Weber AM, Stewart CP, Ratsifandrihamanana L, Fernald LCH. Effects of nutritional supplementation and home visiting on growth and development in young children in Madagascar: a cluster-randomised controlled trial. Lancet Glob Heal. The Author(s). Published by Elsevier Ltd. This is an Open Access article under the CC BY 4.0 license; 2019;7: e1257e1268. doi:10.1016/S2214-109X(19)30317-1

41. Gladstone M, Phuka J, Mirdamadi S, Chidzalo K, Chitimbe F, Koenraads M, et al. The care, stimulation and nutrition of children from 0-2 in Malawi-Perspectives from caregivers; “Who's holding the baby?” PLoS One. 2018;13: 1-20. doi:10.1371/journal.pone.0199757

42. Luo R, Emmers D, Warrinnier N, Rozelle S SS. Using community health workers to deliver a scalable integrated parenting program in rural China: a cluster-randomized controlled trial. Soc Sci Med Sci Med. 2019;239. Available: doi:10.1016/j.socscimed.2019.112545

43. Murray J, Head R, Sarrassat S, Hollowell J, Remes P, Lavoie M, et al. Modelling the effect of a mass radio campaign on child mortality using facility utilisation data and the Lives Saved Tool (LiST): findings from a cluster randomised trial in Burkina Faso. BMJ Glob Heal. 2018;3: e000808. doi:10.1136/bmjgh-2018-000808

44. Higgs ES, Goldberg AB, Labrique AB, Cook SH, Schmid C, Cole CF, et al. Understanding the role of mhealth and other media interventions for behavior change to enhance child survival and development in low-and middle-income countries: An evidence review. J Health Commun. 2014;19: 164-189. doi:10.1080/10810730.2014.929763

45. Sarrassat S, Meda N, Ouedraogo M, Some H, Bambara R, Head R, et al. Behavior change after 20 months of a radio campaign addressing key lifesaving family behaviors for child survival: Midline results from a cluster randomized trial in rural Burkina Faso. Glob Heal Sci Pract. 2015;3: 557-576. doi:10.9745/GHSP-D-15-00153

46. Pereira J, Vickers K, Atkinson L, Gonzalez A, Wekerle C, Levitan R. Parenting stress mediates between maternal maltreatment history and maternal sensitivity in a community sample. Child Abuse Negl. 2012;36: 433-437. 
doi:https://doi.org/10.1016/j.chiabu.2012.01.006

47. Maguire-Jack K, Negash T. Parenting stress and child maltreatment: The buffering effect of neighborhood social service availability and accessibility. Child Youth Serv Rev. Elsevier Ltd; 2016;60: 27-33. doi:10.1016/j.childyouth.2015.11.016

48. Lansford J, (editor) BM. Handbook of Parenting: Volume 5: The Practice of Parenting (3rd ed.) [Internet]. Routledge; Available: https://doi.org/10.4324/9780429401695

49. Bradley RH, Corwyn RF. Caring for children around the world: A view from HOME. Int J Behav Dev. 2005;29: 468-478. doi:10.1177/01650250500146925

50. Britto PR, Ulkuer N. Child development in developing countries: child rights and policy implications. Child Dev. United States; 2012;83: 92-103. doi:10.1111/j.1467-8624.2011.01672.x

\section{Tables}

Table 1a. Caregiver characteristics at baseline, overall and by study arm 


\begin{tabular}{|c|c|c|c|c|c|}
\hline & & $\begin{array}{l}\text { Overall } \\
(n=1004)\end{array}$ & $\begin{array}{l}\text { RM } \\
\text { only } \\
(n=484)\end{array}$ & $\begin{array}{l}\text { RMV- } \\
\text { ECD } \\
(n=520)\end{array}$ & \multirow[t]{2}{*}{$\begin{array}{l}\mathrm{p}- \\
\text { value }\end{array}$} \\
\hline & & \multicolumn{3}{|c|}{$\mathbf{N}(\%)$ or median (IQR) } & \\
\hline Caregiver age in years & Median (IQR) & $\begin{array}{l}26(22 \\
31)\end{array}$ & $\begin{array}{l}26(22, \\
31)\end{array}$ & $\begin{array}{l}27(22 \\
32)\end{array}$ & 0.125 \\
\hline Caregiver sex & Female & $\begin{array}{l}1001 \\
(99.7)\end{array}$ & $\begin{array}{l}484 \\
(100.0)\end{array}$ & $\begin{array}{l}517 \\
(99.4)\end{array}$ & 0.094 \\
\hline \multirow[t]{3}{*}{ Relation to index child } & Mother & $\begin{array}{l}983 \\
(97.9)\end{array}$ & $\begin{array}{l}479 \\
(99.0)\end{array}$ & $\begin{array}{l}504 \\
(96.9)\end{array}$ & \multirow[t]{3}{*}{0.052} \\
\hline & Grandmother & $18(1.8)$ & $5(1.0)$ & $13(2.5)$ & \\
\hline & ratner & $3(0.3)$ & $0(0.0)$ & $3(0.6)$ & \\
\hline \multirow[t]{3}{*}{ Education } & $\begin{array}{l}\text { Not completed } \\
\text { primary }\end{array}$ & $\begin{array}{l}193 \\
(19.2)\end{array}$ & $\begin{array}{l}97 \\
(21.1)\end{array}$ & $\begin{array}{l}96 \\
(18.5)\end{array}$ & \multirow[t]{3}{*}{0.146} \\
\hline & Primary & $\begin{array}{l}700 \\
(68.9)\end{array}$ & $\begin{array}{l}343 \\
(71.0)\end{array}$ & $\begin{array}{l}357 \\
(68.8)\end{array}$ & \\
\hline & seconaary / nigner & $\begin{array}{l}109 \\
(10.9)\end{array}$ & $43(8.9)$ & $\begin{array}{l}66 \\
(12.7)\end{array}$ & \\
\hline Has partner (married, cohabiting) & & $\begin{array}{l}848 \\
(84.5)\end{array}$ & $\begin{array}{l}417 \\
(86.2)\end{array}$ & $\begin{array}{l}431 \\
(82.9)\end{array}$ & 0.153 \\
\hline \multirow[t]{4}{*}{ Partner education } & & $\begin{array}{l}110 \\
(13.0)\end{array}$ & $\begin{array}{l}56 \\
(13.4)\end{array}$ & $\begin{array}{l}54 \\
(12.5)\end{array}$ & \multirow[t]{4}{*}{0.048} \\
\hline & Secondary/higher & $\begin{array}{l}575 \\
(67.8)\end{array}$ & $\begin{array}{l}295 \\
(70.7)\end{array}$ & $\begin{array}{l}280 \\
(65.0)\end{array}$ & \\
\hline & No partner & $\begin{array}{l}163 \\
(19.2)\end{array}$ & $\begin{array}{l}66 \\
(15.8)\end{array}$ & $\begin{array}{l}97 \\
(22.5)\end{array}$ & \\
\hline & & $156(-)$ & $67(-)$ & $89(-)$ & \\
\hline \multirow[t]{2}{*}{ Household living situation } & Nuclear family & $\begin{array}{l}636 \\
(63.3)\end{array}$ & $\begin{array}{l}301 \\
(622)\end{array}$ & $\begin{array}{l}335 \\
(64.4)\end{array}$ & \multirow[t]{2}{*}{0.463} \\
\hline & Extended family & $\begin{array}{l}368 \\
(37.7)\end{array}$ & $\begin{array}{l}183 \\
(37.8)\end{array}$ & $\begin{array}{l}185 \\
(35.6)\end{array}$ & \\
\hline \multirow[t]{3}{*}{ Number of children under 5 in household } & 1 & $\begin{array}{l}478 \\
(47.6)\end{array}$ & $\begin{array}{l}201 \\
(41.5)\end{array}$ & $\begin{array}{l}277 \\
(53.3)\end{array}$ & \multirow[t]{3}{*}{$<.0001$} \\
\hline & $3+$ & $\begin{array}{l}405 \\
(40.3)\end{array}$ & $\begin{array}{l}203 \\
(41.9)\end{array}$ & $\begin{array}{l}202 \\
(38.9)\end{array}$ & \\
\hline & & $\begin{array}{l}121 \\
(12.1)\end{array}$ & $\begin{array}{l}80 \\
(16.5)\end{array}$ & $41(7.9)$ & \\
\hline \multirow[t]{5}{*}{ Household income source } & Farming & $\begin{array}{l}678 \\
(67.7)\end{array}$ & $\begin{array}{l}358 \\
(74.1)\end{array}$ & $\begin{array}{l}320 \\
(61.7)\end{array}$ & \multirow[t]{5}{*}{$<.0001$} \\
\hline & $\begin{array}{l}\text { Self-employ/informal } \\
\text { (business, laborer) }\end{array}$ & $\begin{array}{l}254 \\
(25.3)\end{array}$ & $\begin{array}{l}99 \\
(20.5)\end{array}$ & $\begin{array}{l}155 \\
(29.9)\end{array}$ & \\
\hline & Formal (professional) & $38(3.8)$ & $14(2.9)$ & $24(4.6)$ & \\
\hline & No work & $32(3.2)$ & $12(2.5)$ & $20(3.9)$ & \\
\hline & IVIISSIIIIg & $2(-)$ & $1(-)$ & $1(-)$ & \\
\hline
\end{tabular}




\begin{tabular}{|c|c|c|c|c|c|}
\hline & & $\begin{array}{l}\text { Overall } \\
(n=1004)\end{array}$ & $\begin{array}{l}\text { RM } \\
\text { only } \\
(n=484)\end{array}$ & $\begin{array}{l}\text { RMV- } \\
\text { ECD } \\
(n=520)\end{array}$ & $\begin{array}{l}\mathrm{p}- \\
\text { value }\end{array}$ \\
\hline & & \multicolumn{3}{|c|}{$\mathrm{N}(\%)$ or median (IQR) } & \\
\hline \multirow{5}{*}{$\begin{array}{l}\text { Number of assets (bicycle, motorcycle, car/truck, } \\
\text { animal plough, tractor/tiller, television, } \\
\text { computer/tablet) }\end{array}$} & None & $\begin{array}{l}235 \\
(23.4)\end{array}$ & $\begin{array}{l}120 \\
(24.8)\end{array}$ & $\begin{array}{l}115 \\
(22.1)\end{array}$ & 0.073 \\
\hline & & $\begin{array}{l}692 \\
(68.9)\end{array}$ & $\begin{array}{l}319 \\
(65.9)\end{array}$ & $\begin{array}{l}373 \\
(71.7)\end{array}$ & \\
\hline & & 77 (7.7) & $45(9.3)$ & $32(6.2)$ & \\
\hline & $1-2$ & & & & \\
\hline & $3-7$ & & & & \\
\hline
\end{tabular}

Table 1b. Caregiver characteristics at baseline and endline, by study arm 


\begin{tabular}{|c|c|c|c|c|c|c|c|}
\hline & & \multicolumn{3}{|c|}{ Baseline $(n=1004)$} & \multicolumn{3}{|c|}{ Endline $(n=1004)$} \\
\hline & & $\begin{array}{l}\text { RM only } \\
(n=484)\end{array}$ & $\begin{array}{l}\text { RMV- } \\
\text { ECD }\end{array}$ & $\begin{array}{l}\mathrm{p}- \\
\text { value }\end{array}$ & $\begin{array}{l}\text { RM } \\
\text { only }\end{array}$ & $\begin{array}{l}\text { RMV- } \\
\text { ECD }\end{array}$ & $\begin{array}{l}\mathrm{p}- \\
\text { value }\end{array}$ \\
\hline & & & $(n=520)$ & & $(n=484)$ & $(n=520)$ & \\
\hline & & \multicolumn{2}{|c|}{$\begin{array}{l}N(\%) \text { or other, } \\
\text { specified }\end{array}$} & & \multicolumn{2}{|c|}{$\begin{array}{l}\text { N (\%) or other, } \\
\text { specified }\end{array}$} & \\
\hline Caregiver's index child age in months & Median (IQR) & $\begin{array}{l}12(6 \\
16)\end{array}$ & $\begin{array}{l}11(6, \\
19)\end{array}$ & 0.299 & $\begin{array}{l}26(20 \\
31)\end{array}$ & $\begin{array}{l}26(21 \\
34)\end{array}$ & 0.132 \\
\hline \multirow{2}{*}{$\begin{array}{l}\text { Any under- } 5 \text { years child in household } \\
\text { had injury requiring medical care in } \\
\text { past year }\end{array}$} & \multirow{2}{*}{$\begin{array}{l}\text { No } \\
\text { Yes }\end{array}$} & $\begin{array}{l}413 \\
(85.3)\end{array}$ & $\begin{array}{l}455 \\
(87.5)\end{array}$ & 0.316 & $\begin{array}{l}368 \\
(76.0)\end{array}$ & $\begin{array}{l}418 \\
(80.7)\end{array}$ & 0.073 \\
\hline & & $\begin{array}{l}71 \\
(14.7)\end{array}$ & $\begin{array}{l}65 \\
(12.5)\end{array}$ & & $\begin{array}{l}116 \\
(24.0)\end{array}$ & $\begin{array}{l}100 \\
(19.3)\end{array}$ & \\
\hline \multirow[t]{2}{*}{$\begin{array}{l}\text { Child has had expected number of } \\
\text { under-5 clinic visits since birth }\end{array}$} & \multirow{2}{*}{$\begin{array}{l}\text { No } \\
\text { Yes }\end{array}$} & $\begin{array}{l}347 \\
(71.7)\end{array}$ & $\begin{array}{l}338 \\
(65.0)\end{array}$ & 0.023 & $\begin{array}{l}294 \\
(60.7)\end{array}$ & $\begin{array}{l}251 \\
(48.3)\end{array}$ & $<.0001$ \\
\hline & & $\begin{array}{l}137 \\
(28.3)\end{array}$ & $\begin{array}{l}182 \\
(35.0)\end{array}$ & & $\begin{array}{l}190 \\
(39.3)\end{array}$ & $\begin{array}{l}269 \\
(51.7)\end{array}$ & \\
\hline $\begin{array}{l}\text { Parenting Stress Index (PSI) } \\
\text { (36 items, possible range } 36-180 \text { ) }\end{array}$ & Median (IQR) & $\begin{array}{l}72(59 \\
86)\end{array}$ & $\begin{array}{l}70(57, \\
86)\end{array}$ & 0.486 & $\begin{array}{l}72(62 \\
83)\end{array}$ & $\begin{array}{l}71(59 \\
82)\end{array}$ & 0.135 \\
\hline \multirow{4}{*}{$\begin{array}{l}\text { PSI sub-scales } \\
(12 \text { items each; possible range 12- } \\
60)\end{array}$} & \multirow{4}{*}{$\begin{array}{l}\text { Parental distress } \\
\text { Dysfunction } \\
\text { Difficult Child }\end{array}$} & $\begin{array}{l}28(22 \\
36)\end{array}$ & $\begin{array}{l}28(21, \\
36)\end{array}$ & & $\begin{array}{l}26(21, \\
32)\end{array}$ & $\begin{array}{l}26(21, \\
31)\end{array}$ & 0.468 \\
\hline & & & & 0.770 & & & 0.200 \\
\hline & & $23)$ & $24)$ & 0.064 & $24)$ & $20(16$, & 0.060 \\
\hline & & $\begin{array}{l}24(19 \\
29)\end{array}$ & $\begin{array}{l}23(18 \\
29)\end{array}$ & & $\begin{array}{l}25(21 \\
30)\end{array}$ & $\begin{array}{l}25(20 \\
29)\end{array}$ & \\
\hline \multirow[t]{2}{*}{ PSI cutoff: >90* } & \multirow{2}{*}{$\begin{array}{l}\text { No } \\
\text { Yes }\end{array}$} & $\begin{array}{l}392 \\
(81.0)\end{array}$ & $\begin{array}{l}415 \\
(79.8)\end{array}$ & 0.637 & $\begin{array}{l}396 \\
(84.3)\end{array}$ & $\begin{array}{l}432 \\
(88.3)\end{array}$ & 0.065 \\
\hline & & $\begin{array}{l}92 \\
(19.0)\end{array}$ & $\begin{array}{l}105 \\
(20.2)\end{array}$ & & $\begin{array}{l}74 \\
(15.7)\end{array}$ & $\begin{array}{l}57 \\
(11.7)\end{array}$ & \\
\hline \multirow[t]{6}{*}{ PHQ Depressive symptoms } & None $(<5)$ & $\begin{array}{l}355 \\
(69.2)\end{array}$ & $\begin{array}{l}335 \\
(64.4)\end{array}$ & 0.108 & $\begin{array}{l}312 \\
(64.5)\end{array}$ & $\begin{array}{l}306 \\
(58.9)\end{array}$ & 0.184 \\
\hline & Mild (5-9) & & & & & & \\
\hline & $\begin{array}{l}\text { Moderate (10- } \\
\text { 14) }\end{array}$ & $\begin{array}{l}109 \\
(22.5)\end{array}$ & $\begin{array}{l}149 \\
(28.7)\end{array}$ & & $\begin{array}{l}139 \\
(28.7)\end{array}$ & $\begin{array}{l}1 / 2 \\
(33.1)\end{array}$ & \\
\hline & \multirow{2}{*}{$\begin{array}{l}\text { Moderate/severe } \\
(15-19)\end{array}$} & $29(6.0)$ & $29(5.6)$ & & $22(4.5)$ & $25(6.7)$ & \\
\hline & & $6(1.2)$ & $6(1.1)$ & & $7(1.5)$ & $4(0.8)$ & \\
\hline & Severe $(20+)$ & $5(1.0)$ & $1(0.2)$ & & $4(0.8)$ & $3(0.6)$ & \\
\hline \multirow[t]{5}{*}{ GAD-7 Anxiety symptoms } & None $(<5)$ & $\begin{array}{l}383 \\
(791)\end{array}$ & $\begin{array}{l}403 \\
(77.5)\end{array}$ & 0.771 & $\begin{array}{l}379 \\
(78.3)\end{array}$ & $\begin{array}{l}363 \\
(69.8)\end{array}$ & 0.002 \\
\hline & Mild (5-9) & & & & & & \\
\hline & \multirow{2}{*}{$\begin{array}{l}\text { Moderate (10- } \\
\text { 14) }\end{array}$} & $\begin{array}{l}84 \\
(17.4)\end{array}$ & $(19.2)$ & & $\begin{array}{l}84 \\
(17.3)\end{array}$ & $(27.1)$ & \\
\hline & & $10(2.1)$ & $12(2.3)$ & & $17(3.5)$ & $12(2.3)$ & \\
\hline & Severe (15+) & $7(1.4)$ & $5(1.0)$ & & $4(0.8)$ & $4(0.8)$ & \\
\hline
\end{tabular}




\begin{tabular}{|c|c|c|c|c|c|c|c|}
\hline & & \multicolumn{3}{|c|}{ Baseline $(n=1004)$} & \multicolumn{3}{|c|}{ Endline $(n=1004)$} \\
\hline & & $\begin{array}{l}\text { RM only } \\
(n=484)\end{array}$ & $\begin{array}{l}\text { RMV- } \\
\text { ECD }\end{array}$ & $\begin{array}{l}\mathrm{p}- \\
\text { value }\end{array}$ & $\begin{array}{l}\text { RM } \\
\text { only }\end{array}$ & $\begin{array}{l}\text { RMV- } \\
\text { ECD }\end{array}$ & $\begin{array}{l}\mathrm{p}- \\
\text { value }\end{array}$ \\
\hline & & & $(n=520)$ & & $(n=484)$ & $(n=520)$ & \\
\hline & & \multicolumn{3}{|c|}{$\begin{array}{l}\mathrm{N}(\%) \text { or other, } \\
\text { specified }\end{array}$} & \multicolumn{3}{|c|}{$\begin{array}{l}\mathrm{N}(\%) \text { or other, } \\
\text { specified }\end{array}$} \\
\hline \multirow{8}{*}{$\begin{array}{l}\text { Discipline subscales }{ }^{\star \star} \\
\text { (mean, SD) }\end{array}$} & Psychological & $\begin{array}{l}0.31 \\
(0.38)\end{array}$ & $\begin{array}{l}0.31 \\
(0.35)\end{array}$ & & $\begin{array}{l}0.48 \\
(0.36)\end{array}$ & $\begin{array}{l}0.37 \\
(0.34)\end{array}$ & \\
\hline & (2 items) & & & 0.143 & & & $<.0001$ \\
\hline & $\begin{array}{l}\text { Physical ( } 4 \\
\text { items) }\end{array}$ & $(0.27)$ & $(0.29)$ & 0.509 & $(0.31)$ & $(0.32)$ & 0.941 \\
\hline & Severe physical & & $\begin{array}{l}0.03 \\
(0.12)\end{array}$ & 0.372 & $\begin{array}{l}0.07 \\
(0.21)\end{array}$ & $\begin{array}{l}0.08 \\
(0.22)\end{array}$ & 0.002 \\
\hline & Non-violent & & $\begin{array}{l}0.46 \\
(0.39)\end{array}$ & & $\begin{array}{l}0.77 \\
(0.28)\end{array}$ & $\begin{array}{l}0.71 \\
(0.30)\end{array}$ & \\
\hline & $\begin{array}{l}\text { discipline (3 } \\
\text { items) }\end{array}$ & & & & & & \\
\hline & & $\begin{array}{l}0.02 \\
(0.11)\end{array}$ & & & & & \\
\hline & & $\begin{array}{l}0.48 \\
(0.38)\end{array}$ & & & & & \\
\hline \multicolumn{8}{|c|}{ * At endline, $n=14$ and $n=31$ missing from RM only and RMV-ECD groups, respectively } \\
\hline \multicolumn{8}{|c|}{$\begin{array}{l}\text { ** All discipline item }(n=11) \text { sub-scales are standardized to } 0-1 \text { scale. Violent (negative) discipline behaviors }(n=2) \text { are } \\
\text { described by the psychological (shouted/yelled; called names), physical ( } n=4 ; \text { shook, spanked, hit on bottom, hit arms/legs) } \\
\text { and severe physical ( } n=2 ; \text { beat up, hit in head/face) subscales, and together make the study outcome discipline variable. } \\
\text { The non-violent discipline subscale includes positive discipline behaviors ( } n=3 ; \text { gave something else; explained why wrong; } \\
\text { took away privileges). }\end{array}$} \\
\hline
\end{tabular}

Table 1c. Measures describing potential and reported intervention exposure by study arm 


\begin{tabular}{|c|c|c|c|c|c|c|c|}
\hline & & \multicolumn{3}{|c|}{ Baseline $(n=1004)$} & \multicolumn{3}{|c|}{ Endline $(n=1004)$} \\
\hline & & $\begin{array}{l}\text { RM only } \\
(n=484)\end{array}$ & $\begin{array}{l}\text { RMV- } \\
\text { ECD } \\
(n=520)\end{array}$ & $\begin{array}{l}\mathrm{p}- \\
\text { value }\end{array}$ & $\begin{array}{l}\text { RM } \\
\text { only } \\
(n=484)\end{array}$ & $\begin{array}{l}\text { RMV-ECD } \\
(n=520)\end{array}$ & $\begin{array}{l}\mathrm{p}- \\
\text { value }\end{array}$ \\
\hline & & $\mathbf{N}(\%)$ & & & $\mathbf{N}(\%)$ & & \\
\hline \multirow[t]{4}{*}{ Radio access } & None & $279(55.8)$ & $\begin{array}{l}226 \\
(135)\end{array}$ & $<.0001$ & 238 & 139 & $<.0001$ \\
\hline & Outside household & $19(3.9)$ & & & & & \\
\hline & Within household & $195(40.3)$ & $40(0.8)$ & & $44(9.1)$ & $80(10.5)$ & \\
\hline & & & $\begin{array}{l}248 \\
(47.7)\end{array}$ & & $\begin{array}{l}202 \\
(41.7)\end{array}$ & $\begin{array}{l}295 \\
(56.7)\end{array}$ & \\
\hline \multirow{3}{*}{$\begin{array}{l}\text { Malezi intervention radio } \\
\text { message recall*}\end{array}$} & Not heard & & & & 219 & 132 & $<.0001$ \\
\hline & $\begin{array}{l}\text { Heard but cannot } \\
\text { recall content }\end{array}$ & & & & $23(4.7)$ & $27(5.2)$ & \\
\hline & $\begin{array}{l}\text { Heard and recalled } \\
\text { content }\end{array}$ & & & & $\begin{array}{l}242 \\
(50.0)\end{array}$ & $\begin{array}{l}361 \\
(69.4)\end{array}$ & \\
\hline \multirow{7}{*}{$\begin{array}{l}\text { Frequency heard radio } \\
\text { message }\end{array}$} & Daily & & & & 81 & $88(26.0)$ & 0.056 \\
\hline & Weekly & & & & & 110 & \\
\hline & Monthly & & & & $\begin{array}{l}\text { (29.9) } \\
(29.9\end{array}$ & $(32.6)$ & \\
\hline & $<$ Monthly & & & & 45 & $00(20.0)$ & \\
\hline & Unknown & & & & & (2) & \\
\hline & & & & & $\begin{array}{l}29 \\
(13.1)\end{array}$ & $50(-)$ & \\
\hline & & & & & $44(-)$ & & \\
\hline \multirow[t]{5}{*}{ Last CHW visit } & Never & $557(94.4)$ & 460 & 0.002 & 470 & $28(5.4)$ & $<.0001$ \\
\hline & $3+$ months ago & $10(2.1)$ & & & & $97(18.7)$ & \\
\hline & 1-3 months ago & $11(2.3)$ & & & (1.3) & 208 & \\
\hline & $<1$ month ago & $6(1.2)$ & $33(0.3)$ & & $4(0.8)$ & $(40.0)$ & \\
\hline & & & $16(3.1)$ & & $1(0.2)$ & $\begin{array}{l}187 \\
(36.0)\end{array}$ & \\
\hline \multirow{2}{*}{$\begin{array}{l}\text { Exposure to video ever, in } \\
\text { home or facility }\end{array}$} & No & & & & & $66(12.7)$ & \\
\hline & Yes & & & & & $\begin{array}{l}454 \\
(87.3)\end{array}$ & \\
\hline \multirow{4}{*}{$\begin{array}{l}\text { Exposure to videos in the } \\
\text { home }\end{array}$} & Never & & & & & 79 (15.2) & \\
\hline & $3+$ months ago & & & & & $\begin{array}{l}135 \\
(259)\end{array}$ & \\
\hline & 1-3 months ago & & & & & $145(201)$ & \\
\hline & $<1$ month ago & & & & & $\begin{array}{l}160 \\
(30.8)\end{array}$ & \\
\hline
\end{tabular}




\begin{tabular}{|c|c|c|c|c|c|c|c|}
\hline & & \multicolumn{3}{|c|}{ Baseline $(n=1004)$} & \multicolumn{3}{|c|}{ Endline $(n=1004)$} \\
\hline & & $\begin{array}{l}\text { RM only } \\
(n=484)\end{array}$ & $\begin{array}{l}\text { RMV- } \\
\text { ECD } \\
(n=520)\end{array}$ & \multirow[t]{2}{*}{$\begin{array}{l}\mathrm{p}- \\
\text { value }\end{array}$} & $\begin{array}{l}\text { RM } \\
\text { only } \\
(n=484)\end{array}$ & $\begin{array}{l}\text { RMV-ECD } \\
(n=520)\end{array}$ & \multirow[t]{2}{*}{$\begin{array}{l}\mathrm{p}- \\
\text { value }\end{array}$} \\
\hline & & $\mathbf{N}(\%)$ & & & $N(\%)$ & & \\
\hline \multirow{5}{*}{$\begin{array}{l}\text { Exposure to videos in the } \\
\text { facility }\end{array}$} & Never & & & & & $\begin{array}{l}302 \\
(58.1)\end{array}$ & \\
\hline & $3+$ months ago & & & & & \multirow{2}{*}{78 (15.0) } & \\
\hline & 1-3 months ago & & & & & \multirow{2}{*}{\multicolumn{2}{|c|}{$58(11.1)$}} \\
\hline & \multirow{2}{*}{$<1$ month ago } & & & & & & \\
\hline & & & & & & \multicolumn{2}{|l|}{$82(15.8)$} \\
\hline
\end{tabular}

Table 2. Study outcomes at baseline, endline, and percent of caregivers with improved scores at endline 


\begin{tabular}{|c|c|c|c|c|c|c|c|c|c|}
\hline & \multicolumn{3}{|c|}{ Baseline (BL) status } & \multicolumn{4}{|c|}{ Endline (EL) status } & \multicolumn{2}{|c|}{$\begin{array}{l}\text { Percent caregivers who } \\
\text { move from poor at BL } \\
\text { to good at EL } \\
\text { ( } \mathrm{n}=\text { score well } \\
\text { EL/d=score poor } \mathrm{BL} \text { ) } \\
95 \% \mathrm{Cl}\end{array}$} \\
\hline \multirow[t]{2}{*}{ Column } & 2 & 3 & 4 & 5 & 6 & 7 & 8 & 9 & 10 \\
\hline & $\begin{array}{l}\begin{array}{l}\mathrm{RM} \\
\text { only }\end{array} \\
\mathrm{n}=484 \\
\mathrm{~N}(\%)\end{array}$ & $\begin{array}{l}\text { RMV- } \\
\text { ECD } \\
n=520 \\
N(\%)\end{array}$ & $\begin{array}{l}\mathrm{p}- \\
\text { value* }\end{array}$ & $\begin{array}{l}\text { RM } \\
\text { only } \\
n=484 \\
N(\%)\end{array}$ & $\begin{array}{l}\text { p- } \\
\text { value** } \\
\text { (col } 2 \\
\text { vs 5) }\end{array}$ & $\begin{array}{l}\text { RMV- } \\
\text { ECD } \\
n=520 \\
N(\%)\end{array}$ & $\begin{array}{l}\text { p- } \\
\text { value** } \\
\text { (col } 3 \\
\text { vs } 7)\end{array}$ & $\begin{array}{l}\text { RM only } \\
\mathrm{n}=484\end{array}$ & $\begin{array}{l}\text { RMV-ECD } \\
\mathrm{n}=520\end{array}$ \\
\hline \multicolumn{10}{|c|}{$\begin{array}{l}\text { Early child development } \\
\text { knowledge }\end{array}$} \\
\hline \multirow{2}{*}{$\begin{array}{l}\text { Poor }(<2) \\
\text { Good }(2-6)\end{array}$} & $\begin{array}{l}350 \\
(72.3)\end{array}$ & $\begin{array}{l}332 \\
(63.9)\end{array}$ & 0.004 & $\begin{array}{l}322 \\
(66.4)\end{array}$ & 0.031 & $\begin{array}{l}146 \\
(28.1)\end{array}$ & $<.0001$ & $\begin{array}{l}30.0 \% \\
(105 / 350)\end{array}$ & $\begin{array}{l}65.7 \% \\
(218 / 332)\end{array}$ \\
\hline & $\begin{array}{l}134 \\
(27.7)\end{array}$ & $\begin{array}{l}188 \\
(36.1)\end{array}$ & & $\begin{array}{l}163 \\
(33.6)\end{array}$ & & $\begin{array}{l}374 \\
(71.9)\end{array}$ & & $25.2,35.1$ & $60.3,70.8$ \\
\hline \multicolumn{10}{|c|}{$\begin{array}{l}\text { Early stimulation } \\
\text { practices }\end{array}$} \\
\hline \multirow{2}{*}{$\begin{array}{l}\text { Poor }(<50 \%) \\
\text { Good }(\geq 50 \%)\end{array}$} & $\begin{array}{l}317 \\
(65.4)\end{array}$ & $\begin{array}{l}289 \\
(55.6)\end{array}$ & 0.001 & $\begin{array}{l}315 \\
(65.1)\end{array}$ & 0.886 & $\begin{array}{l}241 \\
(46.5)\end{array}$ & 0.042 & $\begin{array}{l}31.2 \% \\
(99 / 317)\end{array}$ & $\begin{array}{l}49.5 \% \\
(143 / 289)\end{array}$ \\
\hline & $\begin{array}{l}167 \\
(34.5)\end{array}$ & $\begin{array}{l}231 \\
(44.4)\end{array}$ & & $\begin{array}{l}169 \\
(34.9)\end{array}$ & & $\begin{array}{l}277 \\
(53.5)\end{array}$ & & $26.2,36.6$ & $43.6,55.4$ \\
\hline \multicolumn{10}{|l|}{ Father engage } \\
\hline \multirow{2}{*}{$\begin{array}{l}\text { Poor }(<2) \\
\text { Good (2-6) }\end{array}$} & $\begin{array}{l}319 \\
(65.9)\end{array}$ & $\begin{array}{l}339 \\
(65.2)\end{array}$ & 0.811 & $\begin{array}{l}344 \\
(70.9)\end{array}$ & 0.069 & $\begin{array}{l}304 \\
(58.5)\end{array}$ & 0.015 & $\begin{array}{l}23.5 \% \\
(75 / 319)\end{array}$ & $\begin{array}{l}35.4 \% \\
(120 / 339)\end{array}$ \\
\hline & $\begin{array}{l}165 \\
(34.1)\end{array}$ & $\begin{array}{l}181 \\
(34.8)\end{array}$ & & $\begin{array}{l}141 \\
(29.1)\end{array}$ & & $\begin{array}{l}216 \\
(41.5)\end{array}$ & & $19.0,28.6$ & $30.3,40.7$ \\
\hline \multicolumn{10}{|c|}{ Responsive care } \\
\hline \multirow{2}{*}{$\begin{array}{l}\text { Poor }(<5) \\
\text { Good }(5-6)\end{array}$} & $\begin{array}{l}182 \\
(50.1)\end{array}$ & $\begin{array}{l}268 \\
(62.2)\end{array}$ & 0.001 & $\begin{array}{l}178 \\
(50.4)\end{array}$ & 0.866 & $\begin{array}{l}193 \\
(46.5)\end{array}$ & 0.0002 & $\begin{array}{l}51.5 \% \\
(69 / 134)\end{array}$ & $\begin{array}{l}52.3 \% \\
(111 / 212)\end{array}$ \\
\hline & $\begin{array}{l}181 \\
(49.9)\end{array}$ & $\begin{array}{l}163 \\
(37.8)\end{array}$ & & $\begin{array}{l}175 \\
(49.6)\end{array}$ & & $\begin{array}{l}222 \\
(53.5)\end{array}$ & & $42.7,60.2$ & $45.4,59.2$ \\
\hline \multicolumn{10}{|c|}{$\begin{array}{l}\text { Environment/household } \\
\text { safety }\end{array}$} \\
\hline \multirow{2}{*}{$\begin{array}{l}\text { Poor }(\geq 0.3) \\
\text { Good }(<0.3)\end{array}$} & $\begin{array}{l}295 \\
(61.0)\end{array}$ & $\begin{array}{l}201 \\
(38.7)\end{array}$ & $<.0001$ & $\begin{array}{l}208 \\
(42.9)\end{array}$ & $<.0001$ & $\begin{array}{l}182 \\
(35.0)\end{array}$ & 0.213 & $\begin{array}{l}54.6 \% \\
(161 / 295)\end{array}$ & $\begin{array}{l}62.7 \% \\
(126 / 201)\end{array}$ \\
\hline & $\begin{array}{l}189 \\
(39.0)\end{array}$ & $\begin{array}{l}319 \\
(61.3)\end{array}$ & & $\begin{array}{l}277 \\
(57.1)\end{array}$ & & $\begin{array}{l}338 \\
(65.0)\end{array}$ & & $48.7,60.3$ & $55.6,69.4$ \\
\hline \multicolumn{10}{|c|}{$\begin{array}{l}\text { * Chi-square test of distributions of caregivers in MR and RI } \\
\text { ** McNemar's test of caregiver pairs (dependent samples) }\end{array}$} \\
\hline \multicolumn{10}{|c|}{$\begin{array}{l}\text { Description of study outcomes (cut-point for categorical variables is median and each item scores } 1 \text { point, unless otherwise } \\
\text { specified): }\end{array}$} \\
\hline - ECD knowled & of knon & age-app & priate st & nulation & ctivities ( & items) & & & \\
\hline
\end{tabular}


- ES practices: Proportion of age-appropriate stimulation activities done with child on a weekly basis (3 items for infants <6months; 6 items for $6+$ months; standardized score to 0-1 scale).

- Father engage: Number of activities father engaged in past week (6 items; cut-point at top tertile)

- Responsive care: Interviewer-observed responsive care behaviors (4 items, scoring 0-6 points)

- Environment/household safety: Interview-observed environmental or HH (inside/outside) risks (13 items)

Table 3. RMV-ECD compared to RM only intervention effect: Adjusted logistic regression models 


\begin{tabular}{|c|c|c|c|c|c|c|}
\hline & \multicolumn{3}{|c|}{$\begin{array}{l}\text { Adjusted I - baseline status, } \\
\text { child age }\end{array}$} & \multicolumn{3}{|c|}{$\begin{array}{l}\text { Adjusted II - add } \\
\text { covariates }\end{array}$} \\
\hline & OR & $(95 \% \mathrm{Cl})$ & p-value & OR & $(95 \% \mathrm{Cl})$ & $\begin{array}{l}\mathrm{p}- \\
\text { value }\end{array}$ \\
\hline \multicolumn{7}{|l|}{ Early child development knowledge } \\
\hline RMV-ECD arm (ref: RM only) & 4.90 & $(3.16,7.59)$ & $<.0001$ & 4.70 & $\begin{array}{l}\text { (3.07, } \\
\text { 7.19) }\end{array}$ & $<.0001$ \\
\hline ECD knowledge score (0-6) at baseline & 1.25 & $(1.17,1.35)$ & $<.0001$ & 1.24 & $\begin{array}{l}(1.15 \\
1.33)\end{array}$ & $<.0001$ \\
\hline Child age in months & 1.01 & $(0.99,1.03)$ & 0.390 & 1.01 & $\begin{array}{l}(0.99 \\
1.03)\end{array}$ & 0.498 \\
\hline Assets (0-5) & & & & 1.20 & $\begin{array}{l}(1.01 \\
1.43)\end{array}$ & 0.039 \\
\hline Parent Stress Index >90 (endline) & & & & 0.50 & $\begin{array}{l}(0.35 \\
0.71)\end{array}$ & 0.0004 \\
\hline \multicolumn{7}{|l|}{ Early Stimulation practices } \\
\hline RMV-ECD arm (ref: RM only) & 1.88 & $(1.36,2.58)$ & 0.004 & 2.09 & $\begin{array}{l}(1.54 \\
2.83)\end{array}$ & $<.0001$ \\
\hline ES practices score (0-1) at baseline & 3.17 & $(1.54,6.54)$ & 0.003 & 2.72 & $\begin{array}{l}(1.42 \\
5.19)\end{array}$ & 0.004 \\
\hline Child age in months & 1.03 & $(1.00,1.05)$ & 0.031 & 1.02 & $\begin{array}{l}(1.00 \\
1.05)\end{array}$ & 0.071 \\
\hline Caregiver education & & & & 1.00 & (0.50, & \\
\hline$<$ Primary & & & & 0.77 & $(1.57$ & 0.0002 \\
\hline Primary complete & & & & 2.33 & 3.61) & \\
\hline \multicolumn{7}{|l|}{ Secondary+ } \\
\hline Non-violent discipline score (endline) & & & & 1.87 & $\begin{array}{l}(1.58 \\
2.22)\end{array}$ & $<.0001$ \\
\hline \multicolumn{7}{|l|}{ Father engage* } \\
\hline RMV-ECD arm (ref: RM only) & 1.90 & $(1.45,2.48)$ & $<.0001$ & 2.26 & $\begin{array}{l}(1.71 \\
2.99)^{\prime}\end{array}$ & $<.0001$ \\
\hline Father engage score $(0-6)$ at baseline & 1.42 & $(1.31,1.54)$ & $<.0001$ & 1.43 & $\begin{array}{l}(1.29 \\
1.58)\end{array}$ & $<.0001$ \\
\hline Child age in months & 0.99 & $(0.96,1.01)$ & 0.305 & 0.98 & $\begin{array}{l}(0.95 \\
1.02)\end{array}$ & 0.307 \\
\hline Parent Stress Index >90 (endline) & & & & 0.72 & $\begin{array}{l}(0.52 \\
0.99)\end{array}$ & 0.043 \\
\hline Non-violent discipline score (endline) & & & & 1.59 & $\begin{array}{l}(1.34 \\
1.87)\end{array}$ & $<.0001$ \\
\hline \multicolumn{7}{|l|}{ Responsive care } \\
\hline RMV-ECD arm (ref: RM only) & 1.21 & $(0.78,1.86)$ & 0.384 & 1.05 & $\begin{array}{l}(0.69 \\
1.59)\end{array}$ & 0.821 \\
\hline Responsive care scores (0-6) at baseline & 1.05 & $(0.94,1.15)$ & 0.363 & 1.04 & $\begin{array}{l}(0.93 \\
1.16)\end{array}$ & 0.478 \\
\hline
\end{tabular}




\begin{tabular}{|c|c|c|c|c|c|c|}
\hline & \multicolumn{3}{|c|}{$\begin{array}{l}\text { Adjusted I - baseline status, } \\
\text { child age }\end{array}$} & \multicolumn{3}{|c|}{$\begin{array}{l}\text { Adjusted II - add } \\
\text { covariates }\end{array}$} \\
\hline & OR & $(95 \% \mathrm{Cl})$ & p-value & OR & $(95 \% \mathrm{Cl})$ & $\begin{array}{l}\mathrm{p}- \\
\text { value }\end{array}$ \\
\hline Child age in months & 0.96 & $(0.93,0.99)$ & 0.003 & 0.96 & $\begin{array}{l}(0.93 \\
0.99)\end{array}$ & 0.015 \\
\hline Parent Stress Index >90 (endline) & & & & 0.31 & $\begin{array}{l}(0.18 \\
0.54)\end{array}$ & 0.0001 \\
\hline Violent discipline score (endline) & & & & 0.88 & $\begin{array}{l}(0.79 \\
0.97)\end{array}$ & 0.014 \\
\hline \multicolumn{7}{|l|}{ Environmental/household safety } \\
\hline RMV-ECD arm (ref: RM only) & 0.72 & $(0.51,1.02)$ & 0.064 & 0.77 & $\begin{array}{l}(0.56 \\
1.43)\end{array}$ & 0.117 \\
\hline Env/HH safety score (0-8) at baseline & 1.01 & $(0.94,1.08)$ & 0.864 & 1.01 & $\begin{array}{l}(0.93 \\
1.09)\end{array}$ & 0.881 \\
\hline Child age in months & 1.00 & $(0.97,1.02)$ & 0.709 & 1.00 & $\begin{array}{l}(0.97 \\
1.03)\end{array}$ & 0.933 \\
\hline Lives in $\mathrm{HH}$ with extended family members & & & & 1.64 & $\begin{array}{l}(1.32 \\
2.05)\end{array}$ & $<.0001$ \\
\hline $\begin{array}{l}\text { Injury requiring medical care, under- } 5 \text { child in } \mathrm{HH} \text { in } \\
\text { past year }\end{array}$ & & & & 2.03 & $\begin{array}{l}(1.51 \\
2.75)\end{array}$ & $<.0001$ \\
\hline $\begin{array}{l}\text { Child has had expected number of under- } 5 \text { clinic } \\
\text { visits since birth }\end{array}$ & & & & 0.77 & $\begin{array}{l}(0.62 \\
0.96)\end{array}$ & 0.020 \\
\hline
\end{tabular}

\section{* Among caregivers with a partner}

\section{Figures}

\section{$\mathrm{N}=8880$ households enumerated}

$\mathrm{N}=1248$ caregivers recruited and interviewed at baseline

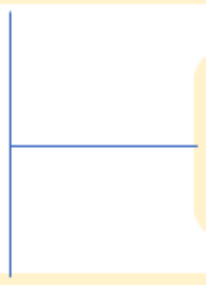

$\mathrm{n}=197$ withdrawn

- 2 determined to be not eligible

- 10 refused after enrolment

- 1 died

- 184 moved out of area

$\mathrm{N}=1051$ followed at endline

- $\mathrm{N}=47$ not traced, or not available for interview after several attempts

$\mathrm{N}=1004$ completed endline interview 


\section{Figure 1}

Study Consort

Page 25/25 